\title{
Sp1 transcription factor binds DNA and activates transcription even when the binding site is CpG methylated
}

\author{
Michael Höller, Gunnar Westin, Joe Jiricny, ${ }^{1}$ and Walter Schaffner \\ Institut für Molekularbiologie II der Universität Zürich, CH-8093 Zürich, Switzerland and ${ }^{1}$ Friedrich Miescher Institut, \\ $\mathrm{CH}-4002$, Basel, Switzerland
}

\begin{abstract}
In vertebrates, a negative correlation between gene activity and CPG methylation of DNA, notably in the promoter region, is well established. Therefore, it is conceivable that differential binding of transcription factors to methylated versus unmethylated binding sites is crucial for gene activity. Since the consensus binding site of transcription factor Sp1 contains a central CpG, we have investigated the binding of Sp1 factor to unmethylated and synthetically CpG-methylated DNA. A strong Sp1 binding site was methylated on both strands at two CpG positions, located in the center and at the periphery of the recognition sequence. Our studies show that neither binding in vitro, nor transcription in vivo and in vitro are affected by methylation of the Sp1 binding site. We discuss the possibility that binding of Sp1 factor, which is often associated with promoters of housekeeping genes, prevents CpG methylation.
\end{abstract}

[Key Words: CpG methylation; DNA-binding protein; transcription factor; transcription regulation]

Received March 28, 1988; revised version accepted July 7, 1988.

CpG is a rare dinucleotide in the DNA of higher eukaryotes (Subak-Sharpe et al. 1966) and in the majority of CpGs the cytidine contains a 5-methyl group. Ten years ago it was observed that several $\mathrm{CpG}$ dinucleotides in the rabbit $\beta$-globin gene were methylated in tissues where the gene was inactive. In erythroid cells, where the gene is expressed, these CpG dinucleotides were essentially unmethylated (Waalwijk and Flavell 1978). Many further examples of an inverse correlation between CpG methylation and gene activity have since been reported (for reviews, see Razin and Riggs 1980; Ehrlich and Wang 1981; Dörfler 1983; Razin and Cedar 1984; Taylor 1984; Cristy and Scangos 1986; Holliday 1987, Cedar 1988). As a result of the activity of a maintenance methylase, the distribution of methylcytidine residues is stably maintained over many cell generations, but induction of differentiation is often accompanied by alterations in the methylation pattern. From the early observations it was not clear whether methylation is the cause of gene inactivation (and vice versa), or rather a side effect of some primary regulatory process. While in some cases loss of methyl groups may lag behind gene activation (Nelson et al. 1984), good evidence for a causal relationship came from demethylation studies using the drug 5-azacytidine. This base analog is incorporated into DNA and inhibits the CpG methylase, presumably by covalent binding, and consequently many methyl groups are lost during subsequent DNA replication (reviewed by Santi et al. 1983; Jones 1985). This can result in the activation of a number of previously silent genes (see, e.g., Compere and Palmiter
1981; Niwa et al. 1983; Davis et al. 1987; for review, see Holliday 1987). Equally convincing is another series of experiments in which genes were methylated in vitro before transfer into eukaryotic cells. For example, methylation of all $\mathrm{CpG}$ dinucleotides in the Moloney retrovirus genome virtually abolishes its expression (Simon et al. 1983), and in simian virus 40 (SV40) methylation of a single HpaII (CCGG) site inhibits late gene transcription when tested in the frog oocytes (Fradin et al. 1982; see also Vardimon et al. 1982). However, it is noteworthy that methylation affects SV40 early promoter function neither in frog oocytes nor in mammalian cells (Fradin et al. 1982; Graessmann et al. 1983). In the $\gamma$ globin gene, the methylation state of the promoter region is most critical for gene expression, whereas extensive methylation of the coding sequence is tolerated (Busslinger et al. 1983; Murray and Grosveld 1987). The simplest interpretation of these findings is that methylation interferes with the binding of transcription factors to DNA. This could occur indirectly, by induction of an altered chromatin structure over the methylated DNA, as was inferred from the delayed inactivation of a methylated TK gene (Buschhausen et al. 1985, 1987; see also Keshet et al. 1986). It is also conceivable that CpG methylation directly inhibits promoter function by sterically hindering the binding of transcription factors.

We have tested the latter possibility with the mammalian transcription factor $\mathrm{Spl}$, because its consensus binding site (Briggs et al. 1986) contains a central CpG dinucleotide. Spl factor has been characterized extensively by R. Tjian and his colleagues. It binds to and ac- 
tivates transcription from many viral and cellular promoters (for review, see Kadonaga et al. 1986). Two polypeptides of $95 \mathrm{kD}$ and $105 \mathrm{kD}$ correlate with $\mathrm{Spl}$ activity (Briggs et al. 1986). Recently a partial cDNA clone of the Spl gene was obtained (Kadonaga et al. 1987). The DNA binding region of the $\mathrm{Spl}$ protein contains three zinc finger motifs analogous to those of the previously characterized TFIIIA factor (Miller et al. 1985). Spl factor indeed requires zinc for DNA binding (Kadonaga et al. 1987) and activator functions (Westin and Schaffner 1988). For our studies, we have used a synthetic Spl binding site which, together with the TATA box, is sufficient to form a strong promoter. We have found that binding of the $\mathrm{Spl}$ factor to this DNA and activation of transcription are completely insensitive to methylation of the CpGs in the recognition site. We propose that $\mathrm{Spl}$ binding prevents DNA methylation and thus may contribute to the maintenance of methylation-free islands that are typically found in the promoter-leader region of housekeeping genes (reviewed by Bird 1986).

\section{Results}

\section{Protein binding studies in vitro}

The synthetic SpNOMET and SpMET oligonucleotides shown in Figure 1A contain within a sequence of $10 \mathrm{bp}$ one strong Sp1 binding site with two CpG dinucleotides. The binding site is derived from the enhancer of the mouse metallothionein I gene and mutated so as to make it a stronger $\mathrm{Spl}$ site. The SpMET oligonucleotide contains two methyl groups on each strand within the binding sequence. These oligonucleotides were used in bandshift experiments (Fried and Crothers 1981; Garner and Revzin 1981). In this assay, an end-labeled doublestranded oligonucleotide is mixed with a nuclear extract from HeLa cells (Westin et al. 1987) and then fractionated by gel electrophoresis. As shown in Figure 1B, a band of retarded mobility was detected, indicating a strong binding complex, and no difference was observed between the methylated and the unmethylated oligonucleotide (lanes 2 and 5, respectively). A similar shift was also obtained with a fragment containing two copies of an Spl site of the immediate-early 3 gene promoter of herpes simplex virus (SpHSV; Fig. 1B, lane 8). As a control for specific binding, all the labeled complexes were competed with a 250 molar excess of unlabeled SpHSV (Fig. 1B, lanes 3, 6, and 9). The same bandshift was observed with an extract from another cell type, namely the human lymphoblastoid cell line BJA-B (Fig. 1C, lanes 3,7 , and 11). Again, methylation did not impair binding, and complexes were eliminated by an excess of unlabeled SpHSV (Fig. 1C, lanes 4, 8, and 12). This shows that the insensitivity of $\mathrm{Spl}$ to methylation of the binding site is not a peculiarity of HeLa cells.

To see whether the methyl groups were preserved in the shifted complex, labeled DNA was extracted from the retarded band and subjected to Maxam and Gilbert sequencing reactions. In addition, we performed the permanganate sequencing reaction where 5 -methyl cytidine is preferentially cleaved rather than unmethylated

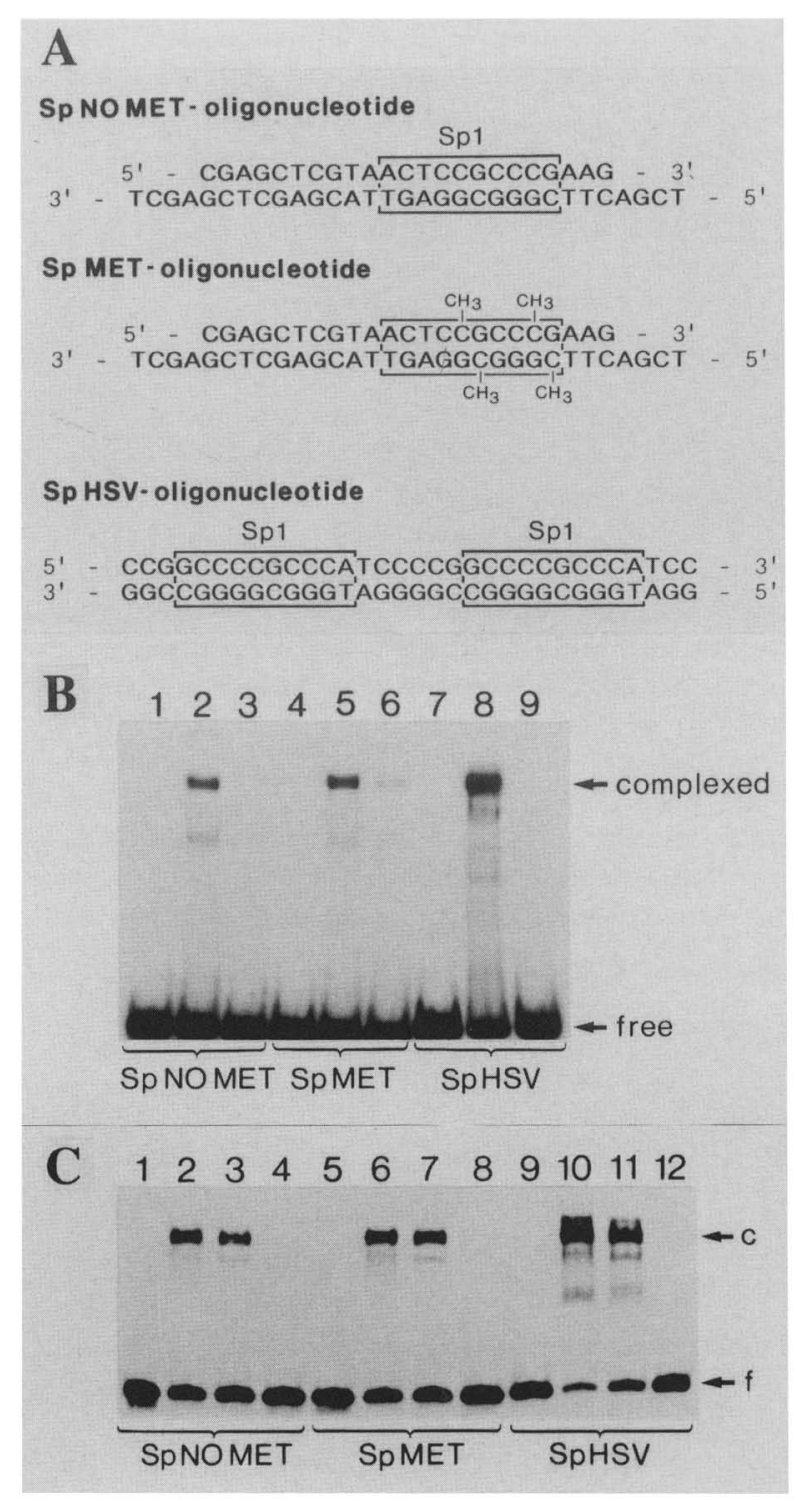

Figure 1. Binding of $\mathrm{Spl}$ factor to methylated and unmethylated recognition sites in vitro. $(A)$ The 31 -bp double-stranded oligonucleotides were derived from the mouse metallothionein I gene (mMT-I) enhancer [the Spl recogntion sites (Briggs et al.1986) are boxed]. One oligonucleotide (SpNOMET) is not CpG methylated, the other is methylated within the binding sequence of $\mathrm{Spl}$ factor (SpMET). The third oligonucleotide (SpHSV) contains two tandem copies of a 16-bp segment from the herpes simplex virus immediate-early 3 (HSV IE-3) gene promoter with a well-characterized Spl site (Jones et al. 1985; Kadonaga et al. 1986). (B) Bandshift analysis with a HeLa cell nuclear extract (Dignam et al. 1983; Westin et al. 1987). End-labeled oligonucleotides SpNOMET (lanes 1-3), SpMET (lanes 4-6) and SpHSV (lanes 7-9). (Lanes 1, 4, and 7) No extract; (lanes 2, 5, and 8), with extract; (lanes 3, 6, and 9) competition with unlabeled SpHSV oligonucleotide. $(C)$ Bandshift analysis with HeLa and human lymphoblastoid cell (BJA-B) extracts. End-labeled SpNOMET oligonucleotide was used in lanes 1-4; SpMET oligonucleotide in lanes 5-8; SpHSV oligonucleotide in lanes 9-12. (Lanes 1, 5, and 9) No extract; (lanes 2, 6 and 10) with HeLa extract; (lanes 3,7 , and 11) with BJA-B extract (lanes 4,8 , and 12) with BJA-B extract and with an excess of unlabeled SpHSV oligonucleotide as a competitor. 
cytidine (Fritzsche et al. 1987). The methylated oligonucleotide in the shifted band was indeed found to be almost completely, if not completely, methylated at both positions (Fig. 2A).

To see whether methylation at other positions affects $\mathrm{Spl}$ binding, we performed a binding interference assay (Siebenlist and Gilbert 1980) with chemically methylated purine bases. The labeled oligonucleotide was subjected to a partial methylation reaction with dimethyl sulfate (DMS). This reagent methylates the N7 position of guanines and the N3 position of adenines in the major and minor grooves, respectively. Partially methylated DNA was incubated with a nuclear extract from HeLa cells and the complexes were separated from free DNA on a native polyacrylamide gel. Both the complexed (c) and the free (f) forms of DNA were eluted from the gel. If any of the methyl groups interfere with binding of transcription factor Spl, that DNA molecule will be under-

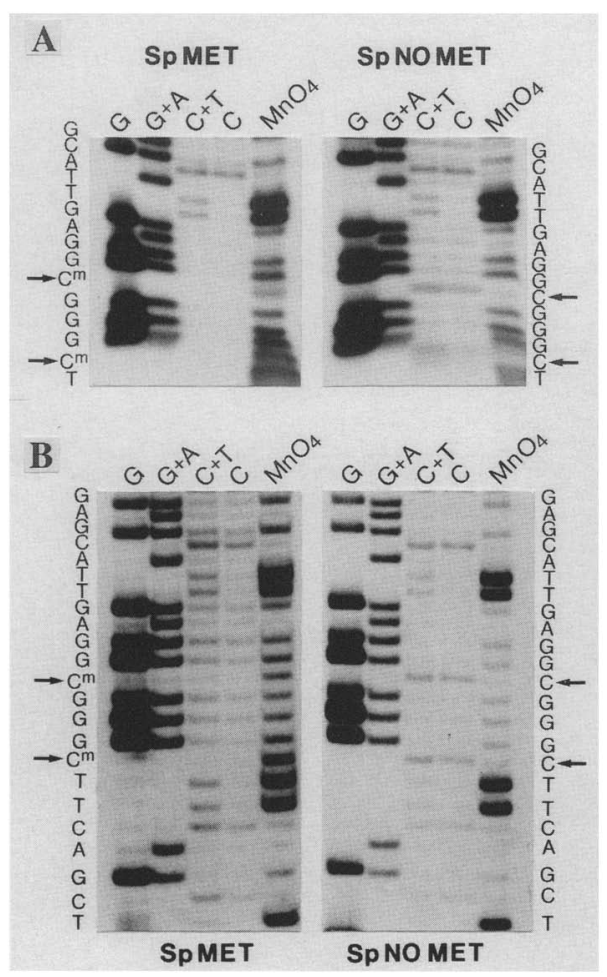

Figure 2. Conservation of $\mathrm{CpG}$ methyl groups under conditions of Spl binding and in vitro transcription. The methylated (SpMET) and the unmethylated (SpNOMET) DNAs were subjected to sequencing reactions following a bandshift gel and recovery of the shifted band $(A)$ or an in vitro transcription reaction $(B)$. In the standard Maxam and Gilbert reaction, unmethylated cytidines appear in the $C$ as well as in the $C+T$ lanes. By contrast, the cytidine band is virtually missing when the position 5 of the pyrimidine ring is methylated. With the permanganate sequencing reaction according to Fritzsche et al. (1987), however, a strong band is seen when the cytidine is methylated. The two cytidines which are diffentially methylated are indicated by arrows. (Faint bands at all nucleotide positions, for example in the $C$ lane of panel $B$, indicate some nonspecific cleavage due to the prolonged incubation in the transcription extract.) represented in the complexed form relative to the unbound DNA. This difference is revealed by missing bands in lane $c$ after cleavage of the DNA backbone with alkali and gel fractionation (Fig. 3A,B). Guanines are more sensitive to $N$-methylation than adenines; therefore, most of the breaks in the DNA backbone occur at guanine residues. The assay revealed that almost every purine within the consensus site, when chemically methylated, prevents Spl binding. The methylation interference pattern was virtually identical for the $\mathrm{CpG}$ methylated DNA and unmethylated DNA, indicating that the same protein is binding to both $\left(\right.$ Fig. $\left.3 \mathrm{~A}^{\prime}, \mathrm{B}^{\prime}\right)$. We note that the interference pattern extends $1-2$ bp beyond the Spl consensus site. Similar results were reported for $\mathrm{Sp} 1$ binding in the U2 snRNA promoter (Janson et al. 1987).

\section{In vitro transcription}

In previous transcription experiments with nuclear extracts of HeLa cells, we had found that four tandem Spl sites placed upstream of a $\beta$-globin TATA box yielded an extremely strong promoter (Westin and Schaffner 1988). In this paper we show that even a single copy of the same Spl site strongly stimulates transcription in vitro. In our experiments, we compared the following four DNA constructs: (1) OVEC expression vector containing a TATA box but no further upstream elements (Westin et al. 1987), as a negative control; (2) unmethylated oligonucleotide (SpNOMET) cloned upstream of the TATA box of OVEC; (3) SpNOMET oligonucleotide ligated, but not cloned, into OVEC; (4) SpMET oligonucleotide ligated into OVEC. The uncloned DNAs ( 3 and 4 ) were made by ligating the oligonucleotides into the expression vector (Fig. 4A) and covalently closed circular DNA was separated from linear and nicked DNA by extraction with acid phenol (Zasloff et al. 1978). In the transcription reactions in vitro, both the directly ligated oligonucleotides, unmethylated as well as methylated, gave the same signal as the cloned (i.e., unmethylated) oligonucleotides (Fig. 4B, lanes 2, 4, and 6). Thus, CpG methylation of the Spl binding site does not inhibit transcription. To establish the linearity of the assay, transcription reactions were performed with various concentrations of template, namely 100,200 , and $400 \mathrm{ng}$ of DNA per 10- $\mu$ l reaction volume (Fig. 4C, lanes 2, 3, and 4). The linear response ruled out the possibility that our templates were transcribed at a maximal rate and thus were not sensitive to variation of promoter activity. In addition, four tandem $\mathrm{Sp} 1$ sites in front of the TATA box (Fig. 4B, lane 7) gave a much stronger signal than a single Sp1 site (Fig. 4B, lane 2), while the TATA box promoter without an $\mathrm{Spl}$ site served as a negative control and yielded only a few transcripts (Fig. 4B, lane 1). These findings show that our assay is performed in a range where even minor differences in transcriptional activity can be recorded. A further control was to check that the methyl groups were maintained during incubation in HeLa nuclear extract. After all, it was conceivable that the $\mathrm{Spl}$ factor appears insensitive to $\mathrm{CpG}$ methylation 
because of a demethylating activity in the extract, perhaps even associated with the Spl factor itself. However, sequencing of the templates after completion of the transcription reaction revealed almost complete, if not complete conservation of the methylated cytidines (Fig. 2B). This experiment, together with a sequencing reaction performed after bandshifting (see above), shows that the methyl groups were not eliminated to a signifi-

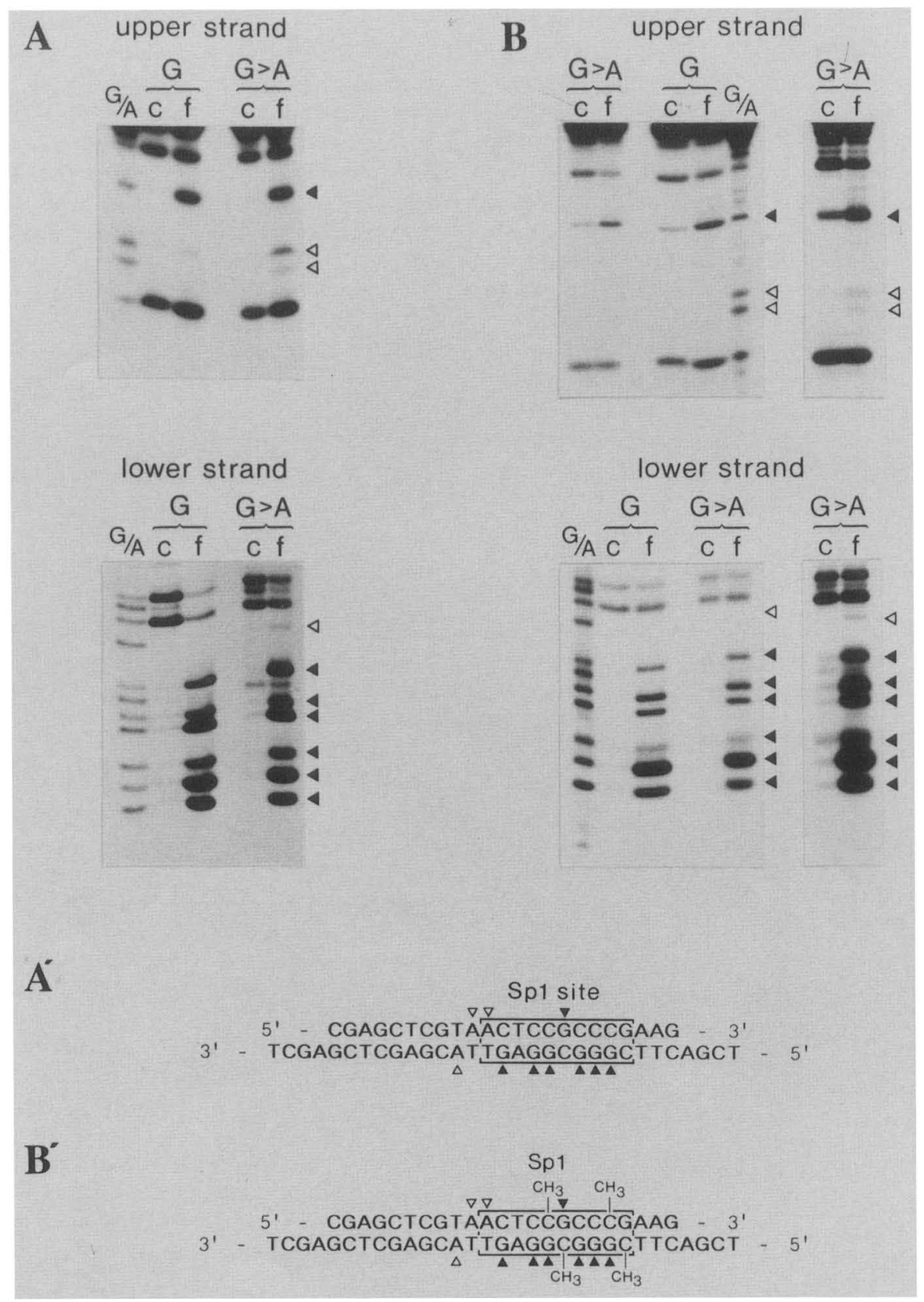

Figure 3. Chemical modification experiments identify purine bases interacting with Spl factor. $(A)$ Both strands of the SpNOMET oligonucleotide carrying an unmethylated $S p l$ recognition sequence were end-labeled and analyzed separately by a chemical modification assay ('methylation interference,' Siebenlist and Gilbert 1980) using HeLa cell nuclear extracts. (Lanes c) Complexed form of DNA from the lower or upper strand; (lanes $f$ ) free, nonshifted DNA from the same binding reaction. Two different cleavage reactions were performed, one that cuts only at modified guanine residues $(G)$ and another that reveals to guanines and to adenines $(G>A)$. $A$ purine-specific $(\mathrm{G} / \mathrm{A})$ sequence reaction indicates the position of the corresponding bases in the oligonucleotides. The lanes to the far right in $B$ depict longer exposures of the $G>A$ reaction. $(B)$ The same procedure as in $A$ was performed with the oligonucleotide containing the CpG methylated Spl recognition sequence. $\left(A^{\prime}\right)$ and $\left(B^{\prime}\right)$ summarize the interference data on the unmethylated and methylated Spl recognition sequence. The triangles indicate the purines whose modification interferes with protein-DNA interaction; solid and open triangles show strong and weaker interference, respectively. The Spl binding site is bracketed. 
cant extent by Spl binding (Fig. 2A) or by the conditions used for the transcription reaction (Fig. 2B).

\section{In vivo transcription}

We wanted to find out whether our in vitro transcription results could be extended to the transcription of DNA transfected into HeLa cells. For this, the same templates were used as before but with the SV40 enhancer inserted downstream of the $\beta$-globin gene (Fig. 4A). The different templates were introduced into HeLa cells by DEAE dextran transfection (de Villiers and Schaffner 1983). Two days after transfection, the RNA was extracted from the cells and transcripts were mapped with an SP6 RNA probe (Fig. 5). Negative and positive controls were also included in this experiment: As with transcription in vitro, omission of the $\mathrm{Spl}$ binding site in front of the TATA box essentially abolished transcription (lane 1), while four copies of the Spl site in front of the TATA box (lane 6) and also the complete $\beta$-globin promoter (lane 2) gave a stronger signal than one copy of the Spl site (lane 3). This indicates that the assay, like the in vitro transcription assay, was in a suitable range of response to transcriptional activity. Most importantly, CpG methylation of the Spl site in the promoter of the template DNA did not affect gene expression after transfection into cells (lanes 4 and 5).

\section{Discussion}

Using three different assays, namely binding of a factor in vitro, and transcription in vitro or in transfected cells, we have shown that $\mathrm{CpG}$ methylation of a binding site for the transcription factor Spl affects neither binding nor transcriptional response. Binding to DNA irrespective of CpG methylation is not a peculiarity of HeLa cells, since it was also seen with extracts from a lymphoblastoid cell line (BJA-B). This finding appears physiologically significant, because other types of methylations introduced at guanine $\mathrm{N} 7$ or adenine $\mathrm{N} 3$ positions do not allow Sp1 binding. The earlier finding that the SV40 early promoter is insensitive to $\mathrm{CpG}$ methylation (Graessmann et al. 1983) can be explained as well, since this promoter contains no less than six Spl sites (Kadonaga et al. 1986).

As with the transcription reaction in vitro, it is not clear what fraction of input DNA molecules was transcribed in vivo. However, it appears unlikely that the methyl groups were removed by transcription: Graessmann et al. (1983) have shown that microinjection of completely methylated polyoma and SV40 DNA into tissue culture cells nonpermissive for viral DNA replication did not affect early gene expression, nor were the methyl groups removed. Stable transfection assays also show conservation of methyl groups (Busslinger et al. 1983; Murray and Grosveld 1987).

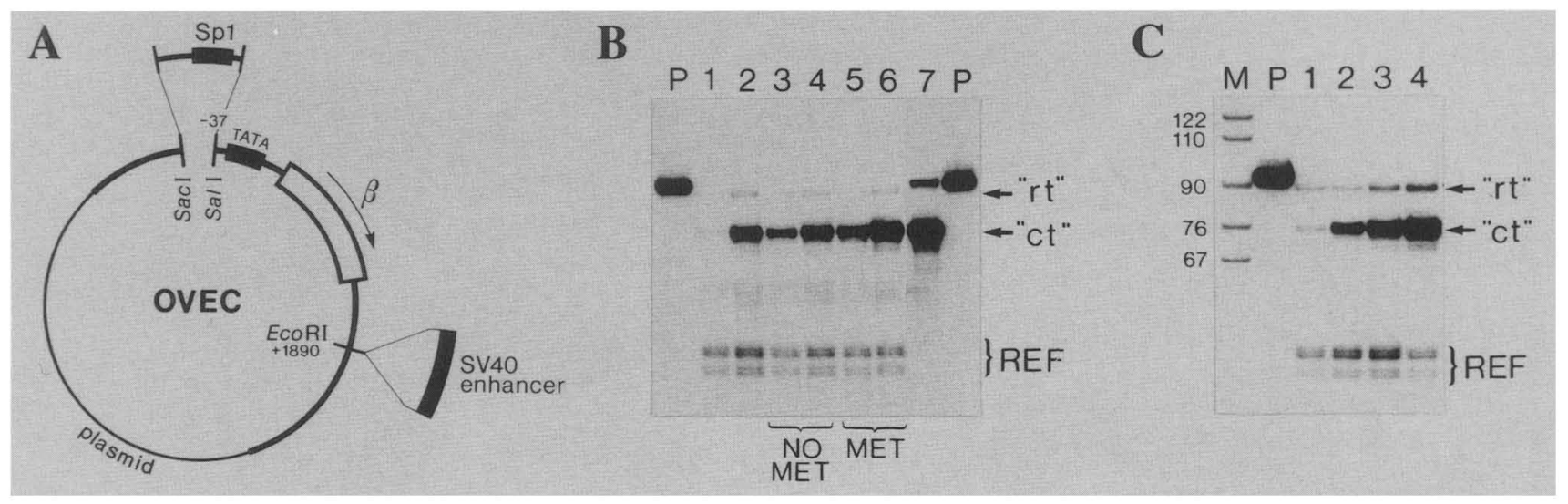

Figure 4. In vitro transcription shows no difference in the activity of methylated and unmethylated Sp1 binding site. Transcripts synthesized from circular templates were analyzed by quantitative S1 nuclease mapping. $(A)$ Map of the expression vector OVEC (Westin et al. 1987). The Spl oligonucleotides were ligated or cloned into the SacI and Sall sites upstream of the rabbit $\beta$-globin gene TATA box. For in vivo analysis a fragment containing the SV40 enhancer was introduced into the EcoRI site downstream of the $\beta$-globin gene. $(B) \mathrm{CpG}$ methylation within the recognition sequence of Spl does not affect transcription in vitro. (Lane 1) OVEC expression vector with TATA box only (400 ng DNA); (lane 2) an Spl binding site (SpNOMET oligonucleotide) cloned 42 bp upstream of the transcription initiation site in the OVEC (200 ng DNA); (lanes 3 and 4) SpNOMET oligonucleotide ligated (but not cloned) into the OVEC vector (lane 3, 100 ng DNA; lane 4, $200 \mathrm{ng}$ DNA); (lanes 5 and 6) SpMET oligonucleotide ligated into the OVEC vector (lane 5, $100 \mathrm{ng}$ DNA; lane 6, $200 \mathrm{ng}$ DNA); (lane 7) four tandemly repeated copies of the SpNOMET oligonucleotide. (Lane P) A 93-nucleotide-long oligonucleotide extending between positions -18 and +75 on the noncoding strand of the $\beta$-globin gene was used as probe. (Lane M) HpaII-digested pBR322 marker DNA. (REF) Reference gene transcripts synthesized from the OVEC-REF plasmid (200 ng DNA) which has a deletion of $28 \mathrm{bp}$ around the transcription initiation site (Westin et al. 1987). (C) The level of correctly initiated transcripts ('ct') increases linearly with template concentration as does the readthrough signal ('rt'). (Lane 1) OVEC expression vector that contains a TATA box as the only upstream promoter element (400 ng DNA); (lanes 2-4) an Sp1 binding site (SpNOMET oligonucleotide) cloned $42 \mathrm{bp}$ upstream of the transcription initiation site in the OVEC vector. (Lane 2) $100 \mathrm{ng}$ of DNA; (lane 3) $200 \mathrm{ng}$ of DNA; (lane 4) $400 \mathrm{ng}$ of DNA. 
Figure 5. The CpG methylated $\mathrm{Spl}$ site is also an efficient promoter element when tested in an in vivo transient assay. HeLa cells were transfected with expression vector DNAs (Fig. 4A) by the DEAE-dextran method and RNA was harvested 2 days later as described by de Villiers and Schaffner (1983). Extracted RNA was analyzed by SP6 RNA mapping. (Lane 1) OVEC with the TATA box as the only upstream transcription element; (lane 2) with complete $\beta$-globin gene promoter; (lane 3 ) with an Spl site (SpNOMET oligonucleotide) cloned into the expression vector OVEC at position -42 upstream of the transcription initiation site; (lane 4) with SpNOMET oligonucleotide ligated (but not cloned) into OVEC at the same position; (lane 5) SpMET oligonucleotide ligated in the same vector; (lane 6) four tandem copies of the SpNOMET oligonucleotide cloned in front of the TATA box of OVEC. All constructs have the SV40 enhancer in a position downstream of the $\beta$-globin test gene. The reference gene OVEC-REF was included as an internal standard (see Fig. 4). Transcripts were mapped with a 279-nucleotide-long SP6

Independently, two other groups have also observed that $\mathrm{Spl}$ binding is largely insensitive to $\mathrm{CpG}$ methylation (Ben-Hattar and Jiricny 1988; Harrington et al. 1988). While in the latter case gene expression was not studied, reduced expression of a methylated template injected into frog oocytes was found in the former. It remains to be seen whether this is, for example, an effect of the relatively weak Spl site used for these studies, or of some chromatin formation peculiar to the frog oocyte. In another laboratory, cell-type-specific expression of the tyrosine aminotransferase (TAT) gene was investigated (Becker et al. 1987). Binding of a putative transcription factor (not Spl) to a sequence far upstream of the TAT promoter was found to be inhibited by $\mathrm{CpG}$ methylation of the binding site. This suggests that $\mathrm{CpG}$ methylation plays a role in the cell-type-specific activation of the TAT gene (Becker et al. 1987). In addition to such direct effects of methylation on the binding of transcription factors, CpG methylation might generally affect chromatin structure even at sites that do not bind transcription factors (Buschhausen et al. 1985; Keshet et al. 1986). This question was not addressed by our experiments.

Most, if not all housekeeping genes (Dynan 1986; Martini et al. 1986; Gardiner-Garden and Frommer 1987; reviewed by Parker et al. 1986) contain so-called methylation-free islands (Cooper et al. 1983; for review, see Bird 1986, 1987). There are some 30,000 such $\mathrm{CpG}$ islands per haploid mammalian genome. CpG islands are thus separated from each other by an average of 100 $k b$, but with great variation about this mean value (Brown and Bird 1986). A typical island spans a region of about $1 \mathrm{~kb}$ and brackets the transcription initiation site. It is rich in $\mathrm{CpG}$ dinucleotides which, unlike most other CpGs of the genome, are not methylated. How are these sites kept free of methylation under almost all circumstances? (Their exceptional methylation in the inactivated $\mathrm{X}$ chromosome might be brought about by some higher-order regulatory mechanism; for a review of the X chromosome, see Gartler and Riggs 1983; Toniolo et al. 1988). We suggest that Spl binding sites, which are

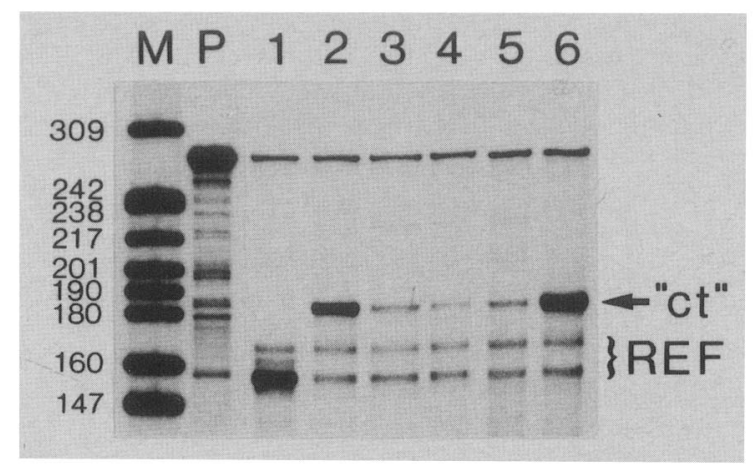

RNA probe (lane $P$ ) derived from the clone pSP6 $\beta$ TS (Westin et al. 1987). 'ct' and REF indicate correctly initiated transcripts and reference gene transcripts, respectively. (Lane M) HpaII-digested pBR322 marker DNA.

frequently present in such methylation-free islands, notably around the site of transcription initiation (Gardiner-Garden and Frommer 1987), are not methylated because Spl factor binds there constitutively. There can be significant de novo methylation of DNA, notably in early embryonic cells (e.g., Niwa et al. 1983). Therefore, we argue that it would be deleterious for a cell to have an $\mathrm{Spl}$ factor that is unable to bind a methylated recognition site. Under such circumstances a promoter would be inactivated if a critical $\mathrm{Sp} 1$ site becomes methylated by chance. Binding and activity of the Spl factor, even in case of fortuitous methylation, should ensure unhampered transcription, which seems particularly imperative for housekeeping genes.

\section{Materials and methods}

Purification and annealing of oligonucleotides

In the SpNOMET and SpMET oligonucleotide three nucleotides of the natural sequence TGCACTCCGCCCG of the mouse metallothionein I gene enhancer were changed to GTAACTCCGCCCG. This creates a better Sp1 binding site, even though the changes are merely in flanking nucleotides rather than within the 10-bp Spl consensus. Oligonucleotides were synthesized on a Pharmacia gene assembler and purified on a $6 \%$ polyacrylamide gel $(19: 1)$ containing $7.5 \mathrm{M}$ urea. The DNA was eluted from the polyacrylamide at room temperature into $1 \mathrm{ml}$ of distilled water, and adsorbed onto a Sep-pak column (Waters Associates, Millipore Corp.) equilibrated with $5 \mathrm{ml}$ of $50 \%$ acetonitrile in $100 \mathrm{~mm}$ sodium acetate $(\mathrm{pH} 4.5)$. The column was washed with $10 \mathrm{ml}$ of distilled water and the DNA was eluted with $2 \mathrm{ml}$ of $30 \%$ acetonitrile in distilled water, lyophilized, and dissolved in $10 \mathrm{mM}$ Tris- $\mathrm{HCl}(\mathrm{pH} 7.5), 1$ mM EDTA. After the kinasing of one single-stranded oligonucleotide in $50 \mathrm{~mm}$ Tris- $\mathrm{HCl}$ (pH 7.6), $10 \mathrm{mM} \mathrm{MgCl}_{2}, 5 \mathrm{~mm}$ DTT, $0.1 \mathrm{mM}$ spermidine, and $0.1 \mathrm{mM}$ EDTA with T4 polynucleotide kinase and $\left[\gamma^{-32}\right]$ ATP, the complementary oligonucleotide was added and the strands were denatured at $90^{\circ} \mathrm{C}$. Annealing was allowed by slowly reducing the temperature to $25^{\circ} \mathrm{C}$.

\section{Purification of covalently closed circular DNA}

After ligation of SpNOMET or SpMET oligonucleotide into the expression vector, DNA was purified by two phenol extractions 
and precipitated with 0.6 volumes of isopropanol at room temperature. DNA was resuspended in $1 \mathrm{mM}$ Tris- $\mathrm{HCl}(\mathrm{pH} 7.5), 1$ mM EDTA, $50 \mathrm{~mm}$ sodium acetate $(\mathrm{pH} 4.0)$, and $75 \mathrm{mM} \mathrm{NaCl}$, and extracted three times with phenol equilibrated with $50 \mathrm{~mm}$ sodium acetate $(\mathrm{pH} 4.0)$. The $\mathrm{pH}$ was adjusted to neutral with 1 $\mathbf{M}$ Tris (pH 9.0), and DNA was concentrated by EtOH precipitation. During the acid phenol extraction, linear and nicked DNA accumulate in the phenol base, whereas the closed circular DNA is quantitatively retained in the water phase (Zasloff et al. 1978).

\section{Detection of 5-methyl cytidine in DNA fragments}

The standard Maxam and Gilbert sequencing reactions (Maxam and Gilbert 1980) yield a ladder of bands in which unmethylated cytidines show up in the $C$ as well as in the $C+T$ reaction. By contrast, the band is virtually missing when the cytidine residue is methylated at position 5 of the pyrimidine ring. Fritzsche et al. (1987) have described the use of permanganate as a sequencing reagent for identification of 5-methyl cytosine residues in DNA. We have also used this method to verify the presence of 5-methyl cytidine in our DNA. The reaction was carried out in $30 \mu \mathrm{l}$ of $20 \mathrm{mM}$ sodium acetate (pH 4.3) and 0.1 $\mathrm{mM} \mathrm{KMnO}_{4}$ for $4 \mathrm{~min}$ at room temperature. The reaction was stopped by adding $2 \mu \mathrm{l}$ of 2-propen-1-ol, and after EtOH precipitation the normal piperidine treatment of the Maxam and Gilbert method was carried out.

\section{Bandshift assay}

Preparation of HeLa cell nuclear extracts was performed as described by Dignam et al. (1983) with minor modifications (Westin et al. 1987). After $\left(\mathrm{NH}_{4}\right)_{2} \mathrm{SO}_{4}$ precipitation, the extract was resuspended in, and dialyzed against, $20 \mathrm{mM} \mathrm{HEPES}-\mathrm{KOH}$ (pH 7.9), 20\% glycerol, $20 \mathrm{mM} \mathrm{KCl}, 2 \mathrm{~mm} \mathrm{MgCl}_{2}, 0.2 \mathrm{~mm}$ EDTA, and $0.5 \mathrm{~mm}$ dithiothreitol (DTT). In the bandshift assay (Fried and Crothers 1981; Garner and Revzin 1981) binding reactions were done by incubating 2-4 fmoles of end-labeled DNA $(5000 \mathrm{cpm})$ with $2-3 \mu \mathrm{g}$ of nuclear protein and $0.5 \mu \mathrm{g}$ poly)(dI-dC) in a buffer containing $15 \mathrm{mM}$ HEPES (pH 7.9), $15 \%$ glycerol, $2 \%$ polyvinylalcohol, $36 \mathrm{~mm} \mathrm{NaCl}, 0.4 \mathrm{mM}$ DTT, and $0.4 \mathrm{mM}$ PMSF at $30^{\circ} \mathrm{C}$ for $20 \mathrm{~min}$ in a final volume of $22 \mu \mathrm{l}$. After the incubation, the reaction mixtures were chilled on ice, loaded on a $4 \%$ polyacrylamide $(29: 1)$ gel in $0.25 \times$ TBE buffer, and electrophoresed at $10 \mathrm{~V} / \mathrm{cm}$ for $1.75 \mathrm{hr}$ at $4^{\circ} \mathrm{C}$. For competition experiments, 2.5 pmoles of double-stranded, annealed oligonucleotide was added to the reaction mixture prior to the addition of the extract. Nuclear extract from a human lymphoblastoid cell line (BJA-B) was prepared as described above. Twice the amount of extract was used in this case.

\section{Chemical modification analysis (DMS methylation interference)}

Studies were carried out in combination with mobility shift experiments using end-labeled double-stranded SpNOMET and SpMET oligonucleotides, both of which were partially methylated for $10 \mathrm{~min}$ at $20^{\circ} \mathrm{C}$ by dimethyl sulfate (DMS) (Siebenlist and Gilbert 1980). As compared to the standard bandshift assay the protein binding reaction was scaled up 16-fold with respect to labeled DNAs, nonspecific competitor, and nuclear cell extract. After electrophoretic separation and autoradiography, the DNA in protein-DNA complex (c in Fig. 1) and the unbound DNA (f in Fig. 1) were excised from the polyacrylamide gel, eluted with $150 \mathrm{~mm} \mathrm{NaCl} / \mathrm{TE}$, purified by DEAE 52 cellulose chromatography and then ethanol-precipitated, followed by the
G-reaction or the G > A-reaction. The G-reaction cleaves at 7methylated $G$ residues and to a lesser extent at 3-methylated $A$ residues. In this case, the DNA pellet was dissolved in $20 \mu \mathrm{l}$ of $10 \mathrm{~mm}$ sodium phosphate buffer $(\mathrm{pH} 7.2)$ and 1 mM EDTA, heated at $90^{\circ} \mathrm{C}$ for $10 \mathrm{~min}$, and chilled on ice. One hundred microliters of $100 \mathrm{~mm} \mathrm{NaOH}$ and $1 \mathrm{~mm}$ EDTA were added and incubation continued for $30 \mathrm{~min}$ at $90^{\circ} \mathrm{C}$. The $\mathrm{pH}$ was adjusted to neutral with $25 \mu \mathrm{l}$ of $1 \mathrm{M}$ Tris- $\mathrm{HCl}(\mathrm{pH} 7.5), 25 \mu \mathrm{l}$ of $2 \mathrm{M}$ sodium acetate buffer (pH 7.0), and $100 \mu \mathrm{l}$ of $200 \mathrm{mM} \mathrm{NaAc} /$ $\mathrm{HAc}$ ( $\mathrm{pH} 4.8$ ). Phenol red was included as a $\mathrm{pH}$ indicator, and the samples were precipitated with ethanol. The DNAs from both the G-reaction and the G > A-reaction were analyzed on a $15 \%$ denaturing polyacrylamide gel (19:1 crosslink).

\section{In vitro transcription assay}

In vitro transcription experiments were done using a HeLa cell nuclear extract (prepared as described above). The SpNOMET oligonucleotide with $\mathrm{SacI}$ and SalI protruding ends was cloned in the SacI and Sall sites of the OVEC vector (Westin et al. 1987 ) in front of the TATA box at position -42 relative to the transcription initiation site. This clone served as a positive control. The OVEC plasmid which contains only the TATA box as an upstream transcription element was used as a negative control. The SpNOMET oligonucleotide as well as the SpMET oligonucleotide were preparatively ligated into the SacI-Sall sites mentioned above. Covalently closed circular DNA molecules were isolated from the ligation reaction by extraction with acid phenol $(\mathrm{pH} 4.0)$ which allows separation of covalently closed circular plasmids from linear and nicked DNA (Zasloff et al. 1978). The DNA concentration was 0.5 pmole DNA per milliliter, with a molar ratio of $1: 1$ of cleaved vector and kinased oligonucleotides, which gave the best yield of monomer circles with a single insert. The concentration of the cloned DNA was measured by $\mathrm{OD}_{260}$, whereas the DNA concentration of the cloned DNA was determined by fluorometry (TKO 100 Mini Fluorometer). The conditions for the in vitro transcription assay were described previously by Westin et al. (1987). The synthesized RNA was analyzed by quantitative S1 nuclease mapping using a 93-nucleotide single-stranded synthetic oligonucleotide extending between positions -18 and +75 of the rabbit $\beta$-globin gene with respect to the transcription initiation site. The samples were fractionated in a $10 \%$ polyacrylamide $\{19: 1) 7.5 \mathrm{M}$ urea gel. In all transcription reactions, the OVEC-REF plasmid, with a deletion of $28 \mathrm{bp}$ around the transcription initiation site, was included as an internal standard.

\section{In vivo transcription}

To achieve efficient transcription in vivo, a 196-bp long fragment containing the SV40 enhancer (de Villiers et al. 1982) was included in all plasmids already used for the in vitro transcription assays. This fragment was inserted into the EcoRI site located 1890-bp downstream of the cap site of the $\beta$-globin test gene. HeLa cells were grown in DMEM supplemented with $2.5 \%$ fetal calf serum, $2.5 \%$ calf serum, $100 \mathrm{U} / \mathrm{ml}$ penicillin, and $100 \mathrm{U} / \mathrm{ml}$ streptomycin, and were transfected with a DNA mixture (ratio between test DNA and REF-DNA $4:$ 1) using the DEAE-Dextran procedure according to the protocol of de Villiers and Schaffner (1983). The DMSO boost (Lopata et al. 1984) was carried out for $3 \mathrm{~min}$ at room temperature with $25 \%$ (vol/ vol) dimethylsulfoxide (DMSO) in Tris-buffered saline (TBS). It was found that chloroquine (Luthman and Magnusson 1983) increased the transfection efficiency even further than with a DMSO boost alone. Therefore, after the DMSO boost the cells 
were incubated for $4 \mathrm{hr}$ at $37^{\circ} \mathrm{C}$ with $100 \mu \mathrm{M}$ chloroquine. The medium was then replaced by normal medium, and the cells were further incubated for $44 \mathrm{hr}$ at $37^{\circ} \mathrm{C}$ in an atmosphere containing $5 \% \mathrm{CO}_{2}$. During this time the cells undergo about two cell-doublings. Harvesting of tissue culture cells and extraction of cytoplasmic RNA was done according to de Villiers and Schaffner (1983). After the residual input plasmid DNA was removed by treatment with RNase-free DNase, RNA was analyzed with a SP6 polymerase-generated RNA probe. The probe was prepared using plasmid pSP6 $\beta$ TS, which is a pSP64 clone containing a 223-bp long TaqI-Sall fragment of OVEC, downstream of the SP6 promoter in an inverted orientation (Westin et al. 1987).

\section{Acknowledgments}

We thank Werner Zürcher (FMI, Basel) and Andreas Heber for synthesizing the oligonucleotides used for our studies, Fritz Ochsenbein for expert graphics work, and Silvia Oberholzer for typing the manuscript. We also thank Drs. Hugh Pelham and Deborah Maguire for critical reading of the manuscript and valuable comments. This work was supported by the Kanton of Zürich and by the Swiss National Science Foundation and by an EMBO long-term fellowship to G.W.

\section{References}

Becker, P.B., S. Ruppert, and G. Schütz. 1987. Genomic footprinting reveals cell type-specific DNA binding of ubiquitous factors. Cell 51: 435-443.

Ben-Hattar, J. and J. Jiricny. 1988. Methylation of single CpGs within the second distal promoter element of the HSV-1 tk gene downregulates its transcription in vivo. Gene 65: 219227.

Bird, A.P. 1986. CpG-rich islands and the function of DNA methylation. Nature 321: 209-213.

-1987. CpG islands as gene markers in the vertebrate nucleus. Trends Genet. 3: 324-347.

Briggs, M.R., J.T. Kadonaga, S.P. Bell, and R. Tjian. 1986. Purification and biochemical characterization of the promoterspecific transcription factor, Sp1. Science 234: 47-52.

Brown, W.R.A. and A.P. Bird. 1986. Long-range restriction site mapping of mammalian genomic DNA. Nature 322: $477-$ 481.

Buschhausen, G., M. Graessmann, and A. Graessmann. 1985. Inhibition of herpes simplex thymidine kinase gene expression by DNA methylation is an indirect effect. Nucleic Acids Res. 13: 5503-5513.

Buschhausen, G., B. Wittig, M. Graessmann, and A. Graessmann. 1987. Chromatin structure is required to block transcription of the methylated herpes simplex virus thymidine kinase gene. Proc. Natl. Acad. Sci. 84: 1177-1181.

Busslinger, M., J. Hurst, and R.A. Flavell. 1983. DNA methylation and the regulation of globin gene expression. Cell 34: 197-206.

Cedar, H. 1988. DNA methylation and gene activity. Cell 53: 3-4.

Compere, S.J. and R.D. Palmiter. 1981. DNA methylation controls the inducibility of the mouse metallothionein-I gene in lymphoid cells. Cell 25: 233-240.

Cooper, D.N., M.H. Taggart, and A.P. Bird. 1983. Unmethylated domains in vertebrate DNA. Nucleic Acids Res. 11: $647-658$.

Cristy, B.A. and G.A. Scangos. 1986. Control of gene expression by DNA methylation. In Molecular genetics of mammalian cells (ed. G.M. Malacinski), pp. 3-29. Macmillan Publishing
Co., New York.

Davis, R.L., H. Weintraub, and A.B. Lassar. 1987. Expression of a single transfected cDNA converts fibroblasts to myoblasts. Cell 51: 987-1000.

de Villiers, J., C. Tyndall, and W. Schaffner. 1982. Transcriptional 'enhancers' from SV40 and polyoma virus show a cell type preference. Nucleic Acids Res. 10: 7965-7976.

de Villiers, J. and W. Schaffner. 1983. Transcriptional 'enhancers' from papovaviruses as components of eukaryotic expression vectors. In Techniques in the life sciences, B5. Nucleic Acid Biochemistry. Elsevier, Ireland.

Dignam, J.D., R.M. Lebovitz, and R.G. Roeder. 1983. Accurate transcription initiation by RNA polymerase II in a soluble extract from isolated mammalian nuclei. Nucleic Acids Res. 11: $1475-1489$.

Dörfler, W. 1983. DNA methylation and gene activity. Annu. Rev. Biochem. 52: 93-124.

Dynan, W.S. 1986. Promoters for housekeeping genes. Trends Genet. 2: 196-197.

Ehrlich, M. and R.Y.-H. Wang. 1981. 5-methylcytidine in eukaryotic DNA. Science 212: 1350-1357.

Fradin, A., L. Manley, and C.L. Prives. 1982. Methylation of simian virus $40 \mathrm{HpaII}$ site affects late, but not early, viral gene expression. Proc. Natl. Acad. Sci. 79: 5142-5146.

Fried, M. and D.M. Crothers. 1981. Equilibria and kinetics of lac repressor-operator interactions by polyacrylamide gel electrophoresis. Nucleic Acids Res. 9: 6505-6525.

Fritzsche, E., H. Hayatsu, G.L. Igloi, S. Iida, and H. Kössel. 1987. The use of permanganate as a sequencing reagent for identification of 5-methylcytosine residues in DNA. $\mathrm{Nu}$ cleic Acids Res. 15: 5517-5528.

Gartler, S.M. and A.D. Riggs. 1983. Mammalian X-chromosome inactivation. Annu. Rev. Genet. 17: 155-190.

Gardiner-Garden, M. and M. Frommer. 1987. CpG islands in vertebrate genomes. J. Mol. Biol. 196: 261-282.

Garner, M.M. and A. Revzin. 1981. A gel electrophoresis method for quantifying the binding of proteins to specific DNA regions: Application to components of the Escherichia coli lactose operon regulatory system. Nucleic Acids Res. 9: 3047-3060.

Graessmann, M., A. Graessmann, H. Wagner, E. Werner, and D. Simon. 1983. Complete DNA methylation does not prevent polyoma and simian virus 40 virus early gene expression. Proc. Natl. Acad. Sci. 80: 6470-6474.

Harrington, M.A., P.A. Jones, M. Imagawa, and M. Karin. 1988. Cytidine methylation does not affect binding of transcription factor Spl. Proc. Natl. Acad. Sci. 85: 2066-2070.

Holliday, R. 1987. The inheritance of epigenetic defects. Science 238: 163-170.

Janson, L., Ch. Bark, and U. Pettersson. 1987. Identification of proteins interacting with the enhancer of human U2 small nuclear RNA genes. Nucleic Acids Res. 15: 4997-5016.

Jones, P.A. 1985. Altering gene expression with 5-azacytidine. Cell 40: 485-486.

Kadonaga, J.T., K.A. Jones, and R. Tjian. 1986. Promoter-specific activation of RNA polymerase II transcription by $\mathrm{Spl}$. Trends Biol. Sci. 11: 20-23.

Kadonaga, J.T., K.R. Carner, F.R. Masiarz, and R. Tiian. 1987. Isolation of cDNA encoding transcription factor $\mathrm{Spl}$ and functional analysis of the DNA binding domain. Cell 51: 1079-1090.

Keshet, I., J. Lieman-Hurwitz, and H. Cedar. 1986. DNA methylation affects the formation of active chromatin. Cell 44: $535-543$.

Lopata, M.A., D.W. Cleveland, and B. Sollner-Webb. 1984. High level transient expression of a chloramphenicol acetyl 
transferase gene by DEAE-dextran mediated DNA transfection coupled with a sulfoxide or glycerol shock treatment. Nucleic Acids Res. 12: 5707-5715.

Luthman, H. and G. Magnusson. 1983. High efficiency polyoma DNA transfection of chloroquine treated cells. Nucleic Acids Res. 11: 1295-1308.

Martini, G., D. Toniolo, T. Vulliamy, L. Luzzatto, R. Dono, G. Viglietto, G. Paonessa, M. D’Urso, and M.G. Persico. 1986. Structural analysis of the X-linked gene encoding human glucose 6-phosphate dehydrogenase. EMBO J. 5: 1849-1855.

Maxam, A.M. and W. Gilbert. 1980. Sequencing end-labeled DNA with base-specific chemical cleavages. Methods Enzymol. 65: 499-560.

Miller, J., A.D. McLachlan, and A. Klug. 1985. Repetitive zincbinding domains in the protein transcription factor IIIA from Xenopus oocytes. EMBO I. 4: 1609-1614.

Murray, E. and F. Grosveld. 1987. Site-specific demethylation in the promoter of human gamma-globin gene does not alleviate methylation mediated suppression. EMBO /. 6: 23292335.

Nelson, K.J., E.L. Mather, and R.P. Perry. 1984. Lipopolysaccharide-induced transcription of the kappa immunoglobulin locus occurs on both alleles and is independent of methylation status. Nucleic Acids Res. 12: 1911-1923.

Niwa, O., Y. Yokota, H. Ishida, and T. Sugahara. 1983. Independent mechanisms involved in suppression of the Moloney leukemia virus genome during differentiation of murine teratocarcinoma cells. Cell 12: 1105-1113.

Parker, J.-H., H.V. Hershey, and M.W. Taylor. 1986. Housekeeping genes. In Molecular genetics of mammalian cells (ed. G.M. Malacinski), pp. 79-98. Macmillan Publishing Co., New York.

Razin, A. and A.D. Riggs. 1980. DNA methylation and gene function. Science 210: 604-610.

Razin, A. and H. Cedar. 1984. DNA methylation in eukaryotic cells. Int. Rev. Cytol. 92: 159-185.

Santi, D.V., Ch.E. Garrett, and Ph.J. Barr. 1983. On the mechanism of inhibition of DNA-cytosine methyltransferases by cytosine analogs. Cell 33: 9-10.

Siebenlist, U. and W. Gilbert. 1980. Contacts between Escherichia coli RNA polymerse and an early promoter of phage T7. Proc. Natl. Acad. Sci. 77: 122-126.

Simon, D., H. Stuhlmann, D. Jähner, H. Wagner, E. Werner, and R. Jaenisch. 1983. Retrovirus genomes methylated by mammalian but not bacterial methylase are non-infectious. $\mathrm{Na}$ ture 304: 275-277.

Subak-Sharpe, H., R. Bürki, R. Crawford, J.M. Morrison, J. Hay, and H.M. Keir. 1966. An approach to evolutionary relationships of mammalian DNA viruses through analysis of the pattern of nearest neighbor base sequences. Cold Spring Harbor Symp. Quant. Biol. 31: 737-748.

Taylor, J.H. 1984. DNA methylation and cellular differentiation. Springer-Verlag, Vienna and New York.

Toniolo, D., G. Martini, B.R. Migeon, and R. Dono. 1988. Expression of the G6PD locus on the human $\mathrm{X}$ chromsome is associated with demethylation of three $\mathrm{CpG}$ islands within $100 \mathrm{~kb}$ of DNA. EMBO J. 2: 401-406.

Vardimon, L., A. Kressmann, H. Cedar, M. Mächler, and W. Dörfler. 1982. Expression of a cloned adenovirus gene is inhibited by in vitro methylation. Proc. Natl. Acad. Sci. 79: 1073-1077.

Waalwijk, C. and R.A. Flavell. 1978. DNA methylatin at a CCGG sequence in the large intron of the rabbit $\beta$-globin gene: tissue-specific variations. Nucleic Acids Res. 5: 46314641.

Westin, G., T. Gerster, M.M. Müller, G. Schaffner, and W.
Schaffner. 1987. OVEC, a versatile system to study transcription in mammalian cells and cell-free extracts. Nucleic Acids Res. 15: 6787-6798.

Westin, G. and W. Schaffner. 1988. Heavy metal ions in transcription factors from HeLa cells: Spl, but not octamer transcription factor requires zinc for DNA binding and for activator function. Nucleic Acids Res. 16: 5771-5782.

Zasloff, M., D. Gordon, and G. Felsenfeld. 1978. A new method for the purification and identification of covalently closed circular DNA molecules. Nucleic Acids Res. 5: 1139-1151. 


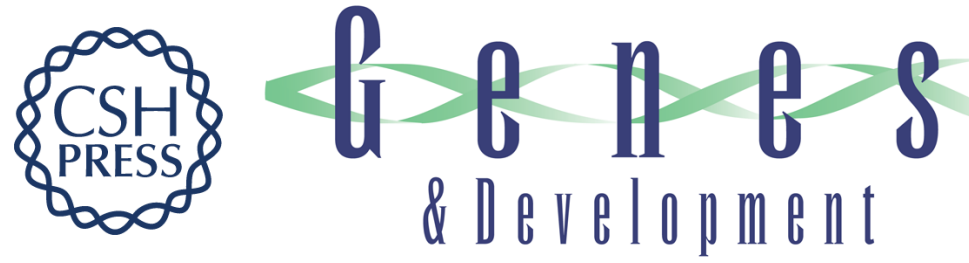

\section{Sp1 transcription factor binds DNA and activates transcription even when the binding site is $\mathrm{CpG}$ methylated.}

M Höller, G Westin, J Jiricny, et al.

Genes Dev. 1988, 2:

Access the most recent version at doi:10.1101/gad.2.9.1127

References This article cites 52 articles, 11 of which can be accessed free at: http://genesdev.cshlp.org/content/2/9/1127.full.html\#ref-list-1

License

Email Alerting

Service

Receive free email alerts when new articles cite this article - sign up in the box at the top right corner of the article or click here.

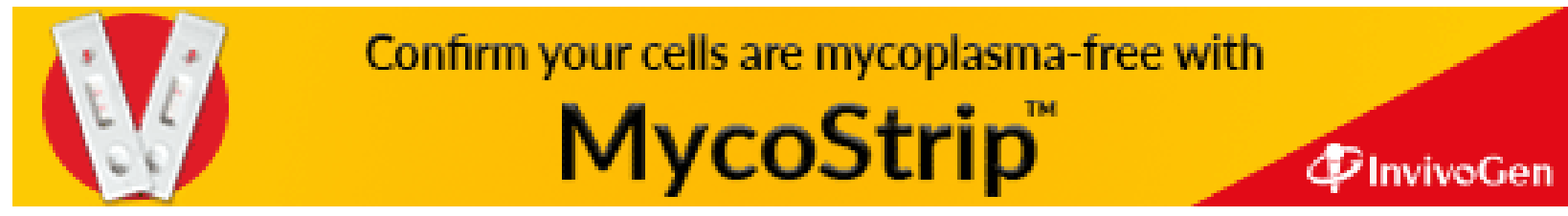

